\title{
The Effect of Organizational Culture and Work Motivation on Teachers Performance of Public Senior High School in Tebing Tinggi
}

\author{
Nasrun, Dody Feliks Pandimun Ambarita
}

State University of Medan, Medan, Indonesia

e-mail: nasrun.nst@gmail.com

\begin{abstract}
This study aims to find out: (1) the effect of organizational culture on work motivation; (2) the effect of organizational culture on teachers performance; and (3) the effect of work motivation on teachers performance. The population in this study were all teachers of public senior high school in Tebing Tinggi as many as 297 people. In determining the sample, the researcher refers to Arikunto's criteria that is taking $37 \%$ (110 people) of the population. To determine the sample of each school is used proportional random sampling technique. The instrument to collect the data were questionnaires based on the Likert Scale model. The validity was computed using the Product Moment Correlation formula while the reliability was tested using the Alpha Cronbach formula. This causal model was tested using the path analysis. Based on the analysis, obtained that: (1) organizational culture had a direct effect on work motivation with a path coefficient of 0,$296 ;$; (2) a direct effect of organizational culture on teachers performance with a path coefficient of 0,185 ; and (3) work motivation had a direct effect on teachers performance with a path coefficient of 0,297 . Based on the results of the study, the three hypotheses enforced is accepted. Therefore, the efforts to strenghen and improve organizational culture and work motivation can increace teachers performance.
\end{abstract}

Keywords: Organizational Culture, Work Motivation, Teachers Performance 


\section{INTRODUCTION}

A country can be said onward if the education in the country has produced a good output through a good process. A good process in the field of education is systematic learning systematically conducted by educational providers to learners. Educational providers are all things that participate in the case of the progress of education implementation either established by the government or established by the private. In the case of systematic learning, it is necessary to conduct training and competence development for educational providers (educators). According to Sutrisno (2014:20) that the educators are teachers, parents, community leaders and anyone who serves to educate. To function as an educator, an educator needs to understand his or her task. Tim Pengembang Ilmu Pendidikan FIP - UPI (2007:9) stated that the task of educators is helping learners do learning activities. With the task is expected that educators (teachers) are able to function him/herself as an educator.

A person's professionalism is shown through their attitude or behavior in terms of doing the profession or the task. In order to carry out the task, a person must have certain qualifications to be a professional person. Similarly the profession of teachers, teachers as a medium of learning at once learners must do everything that is necessary for the realization of the shared ideals namely to educate the life of nation (Preambule Pancasila alinea ke-4). This is in line with the Undang-Undang Republik Indonesia nomor 20 tahun 2003 tentang Sistem Pendidikan Nasional pasal 3. For the realization of shared ideals, it is necessary to do synergicity between educational providers and learners in order to create graduates who believe in God, morals, noble, healthy, knowledgeable, capable, creative, independent, and become a democratic and responsible citizen.

The professionalism of a teacher is not only measured by being able to function him/herself as an educator but also able to develop his/her competence in teaching to fit with the demands of the era and national educational goals. The professionalism of a teacher will appear through the performance of a teacher. According to the Tim Pusat Studi Pancasila UGM (2015:491) that the performance of teachers is the ability shown by the teacher in performing the task or work. In reality the performance of a teacher is still relatively low, it is seen in the UKG conducted by the government in order to make the mapping of teacher competence. In an electronic newspaper website OKEZONE Online, JAKARTA, Tuesday November 1st, 2016 - Teacher competence in teaching is still low. Based on the results of the Teacher Competency Test (UKG) 2016, the average value is still below the standard, which is 53 from a maximum value of 100 .

This makes the government perform certification (teacher professionalization training held by LPTK which was determined by the government) in order to improve teacher competence through increasing teachers' welfare. However, this is considered the absence of linear correlation between the improving teacher competence and the increasing teachers' welfare. This is in accordance with Darmaningtyas (2005:145) stated that although President B.J. Habibie and Gus Dur have succeeded in increasing the salary of teachers of the country doubled, not automatically the performance of the teachers of the country along with the increase of their welfare. The performance of state teachers still remains as before: lazy, often permission do not teach, low curiosity, do not update the information or knowledge, have no principles, and so on. In other words, teacher salaries doubled did not have an impact on teacher quality improvement. From the explanation above, it can be concluded that the performance of a teacher not only can be improved through increasing the welfare of a teacher but also there are more important things in order to improve the performance of a teacher.

One of the predicted factors that can improve teacher performance is organizational culture. McShane and Von Glinow (2008:460) said that strong organizational culture has the potential to improve performance, and vice versa when weak organizational culture leads to decrease performance. The next factor that predicted can affect the teachers performance is the work motivation that comes from the teacher. Winardi (2002:6) suggested work motivation is a potential force that exists in a person that can be developed by a number of external force that essentially revolves around monetary rewards, reward nonmoneter that can affect the results of its performance positively or negatively, which depends on the situation and the conditions encountered. This is in line with the opinion of Colquitt, et al. (2009:34) stated that the factors that affected performance such as: organizational culture, organizational structure, leadership and influence of leader, group process, 
group character, individual ability and cultural values in organization, job satisfaction, ability to manage stress, motivation achievement, punishment, learning and decision making.

Based on the description above, it is necessary to conduct research to examine the teachers performance and the variables that influenced it i.e. organizational culture and work motivation.

Mangkunegara (2008:113) said that organizational culture is the set of assumptions or belief systems, values and norms that are developed in the organization as behavioral guidelines for its members to resolve external adaptation and internal integration issues. Furthermore, according to Newstrom (as cited in: Ambarita, et al., 2014:7) that organizational culture is the set of assumptions, beliefs, values, and norms that are shared by organization members. In line with this, Robbins and Judge (2011:521) stated that organizational culture is a system of shared meaning held by members that distinguishes the organization from other organizations. Further, Robbins and Judge (2009:608) made the correlation model of organizational culture with performance and satisfaction, as seen in the Figure 1.

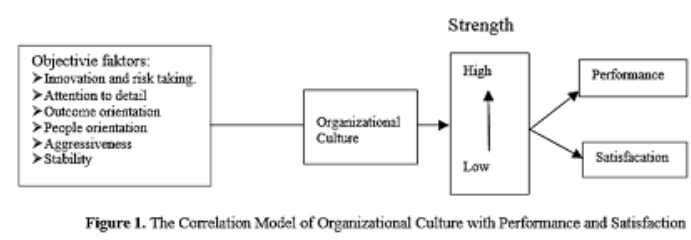

Based on the Figure 1, it can be explained that the organizational culture directly affects satisfaction and performance.

While according to Colquitt, et al. (2009:64) that individual outcomes can be affected by organizational mechanisms, group mechanisms, individual characteristics, and individual mechanisms, as seen in the following figure 2 .

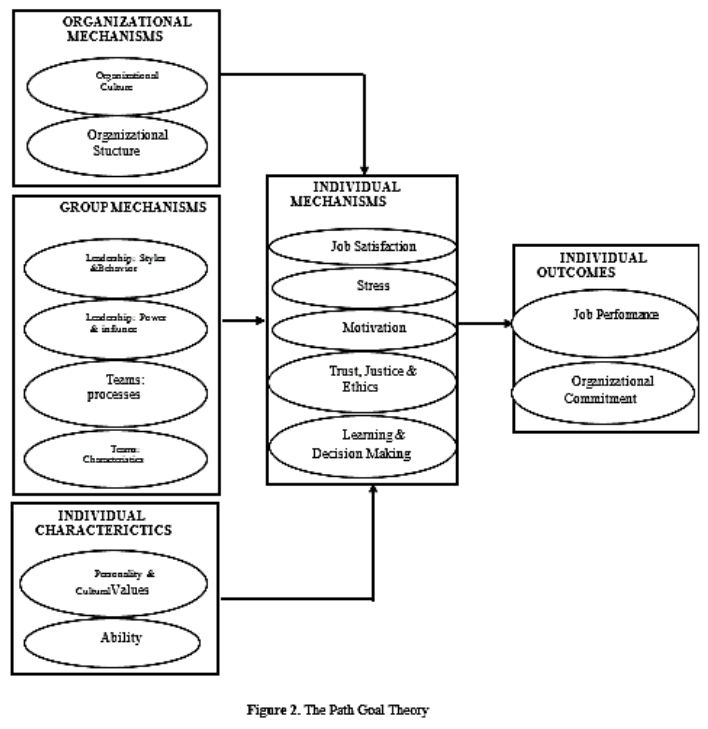

Based on the Figure 2, it can be explained that job performance can be affected by motivation, motivation can be affected by organizational culture.

According to Gibson (2007:103) that work motivation is a power in someone self that is able to encourage someone to do something that creates and directs behavior. Furthermore, McCormick (as cited in: Mangkunegara, 2013:94) said that work motivation is defined as conditions which influence the arousal, direction, and maintenance of behaviors relevant in work settings.

Uno (2011:71) declared that work motivation is one factor that also determine the performance of a person. High or low the influence of motivation on a person performance depends on how much motivation intensity is given. While according to Colquitt, et al. (as cited in: Ambarita, et al., 2014:180) that motivation has a strong positive effect on job performance. People who experience higher levels of motivation tend to have higher levels of task performance, as seen in the Figure 3.

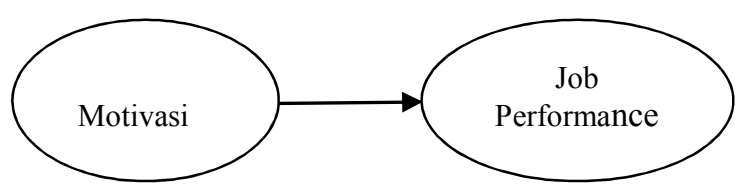

Figure 3. The Effect of Motivation on Performance

In line with this, Robbins and Judge (as cited in: Hasibuan, 2014:60) suggested the expectancy theory. The expectancy theory is a theory that suggests the power of the tendency to act 
in a certain way depends on the strength of a hope that action will be followed by the given outcome and the appeal of that result to the individual.

Based on the Figure 4, it can be argued that individual performance is directly influenced by individual effort, individual performance directly affects personal goals. The theory explains that if a person is motivated to do harder effort, his performance will increase, good performance will lead to the addition of organizational rewards, and further rewards (bonuses, salary increases) will meet the personal goals of the worker.

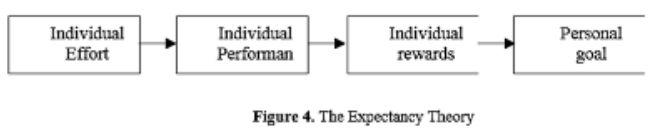

Based on the explanations above, then the work motivation is encouragement in a person self to perform something in order to get what is aspired.

In Indonesian Big Dictionary (Depdikbud, 1990:503) performance means something that is achieved, performance is demonstrated or work ability. While Sutrisno (2010:172) stated that the performance is the work of a person, seen in the aspects of quality, quantity, working time, and cooperation to achieve goals that have been established by organization/ school. Furthermore, according to Sihombing (2010:14) that the teacher performance can be interpreted as the results of the work accomplished by the teacher in accordance with the authority and responsibility based on the knowledge, attitude, skills, and motivation in the implementation of duty.

Based on the theories above, it can be concluded that the teachers performance is an assessment obtained by a teacher due to the implementation of these responsibilities in the learning process in order to achieve the goal.

The hypothesis were formulated as follows: (1) organizational culture $\left(\mathrm{X}_{1}\right)$ had a direct positive effect on teachers work motivation $\left(\mathrm{X}_{2}\right)$ of SMA Negeri in Tebing Tinggi; (2) organizational culture $\left(\mathrm{X}_{1}\right)$ had a direct positive effect on teachers performance $\left(\mathrm{X}_{3}\right)$ of SMA Negeri in Tebing Tinggi; and (3) teachers work motivation $\left(\mathrm{X}_{2}\right)$ had a direct positive effect on teachers performance $\left(\mathrm{X}_{3}\right)$ of SMA Negeri in Tebing Tinggi.

\section{RESEARCH METHOD}

The population in this study were all teachers of public senior high school in Tebing Tinggi with the number of 297 people. In determining the number of samples used $37 \%$ of the population (Arikunto, 2008:116) and proportional random sampling technique. Thus, it was obtained the number of sample as many as 110 people, as seen in the Table 1.

Table 1. Distribution of Sample of Public Senior High School in Tebing Tinggi

\begin{tabular}{|c|c|c|}
\hline No. & Name of School & Sample \\
\hline 1 & SMA Negeri 1Tebing Tinggi & $37 / 100 \times 81=30$ \\
\hline 2 & SMA Negeri 2 Tebing Tinggi & $37 / 100 \times 76=28$ \\
\hline 3 & SMA Negeri 3 Tebing Tinggi & $37 / 100 \times 74=27$ \\
\hline 4 & SMA Negeri 4 Tebing Tinggi & $37 / 100 \times 66=25$ \\
\hline \multicolumn{2}{|c}{ Total } & 110 \\
\hline
\end{tabular}

The instrument for collecting the data were questionnaires based on Likert Scale model of which validity and reliability had been tested. The validity was computed using the Product Moment Correlation formula while the reliability was tested using the Alpha Cronbach formula. This causal model was tested using the path analysis. The path analysis was done to confirm the views by Sugiyono (2012:297) that stated path analysis is used to illustrate and test the correlation model between variables in the form of cause and effect (not the form of interactive / reciprocal correlation).

\section{RESEARCH FINDING AND DISCUSSION}

\subsection{Validity and Reliability}

Based on the result of testing, the validity of items of each instrument is seen in Table 2 below.

Table 2. Validity of Items of Each Instrument

\begin{tabular}{|c|c|c|c|}
\hline Variable & $\begin{array}{c}\text { Total Items } \\
\text { Tested }\end{array}$ & $\begin{array}{c}\text { Items Not } \\
\text { Valid }\end{array}$ & $\begin{array}{c}\text { Items } \\
\text { Valid }\end{array}$ \\
\hline $\begin{array}{c}\text { Organizational } \\
\text { Culture }\end{array}$ & 35 & 13 & 22 \\
\hline Work Motivation & 30 & 7 & 23 \\
\hline $\begin{array}{c}\text { Teachers } \\
\text { Performance }\end{array}$ & 32 & 9 & 23 \\
\hline
\end{tabular}

Based on the reliability test, instrument said to be reliable if $\alpha>0,70$. The reliability test result is illustrated in Table 3. 
Table 3. Reliability Test Result

\begin{tabular}{|c|c|c|c|}
\hline Variable & $\begin{array}{c}\text { Total } \\
\text { Items }\end{array}$ & $\boldsymbol{\alpha}$ & Explanation \\
\hline $\begin{array}{c}\text { Organizational } \\
\text { Culture }\end{array}$ & 22 & 0,880 & Reliable \\
\hline Work Motivation & 23 & 0,914 & Reliable \\
\hline $\begin{array}{c}\text { Teachers } \\
\text { Performance }\end{array}$ & 23 & 0,919 & Reliable \\
\hline
\end{tabular}

\subsection{Data Description} presented in Table 4

The data description of three variables is

Table 4. Data Description of Three Variables

\begin{tabular}{|c|c|c|c|c|}
\hline \multirow{2}{*}{ No } & Descriptive Statistic & \multicolumn{3}{|c|}{ Variable } \\
\cline { 3 - 5 } & & $\mathbf{X}_{\mathbf{1}}$ & $\mathbf{X}_{\mathbf{2}}$ & $\mathbf{X}_{\mathbf{3}}$ \\
\hline 1. & Sample & 110 & 110 & 110 \\
\hline 2. & Mean & 89,55 & 85,33 & 83,35 \\
\hline 3. & Median & 83,76 & 87,84 & 83,18 \\
\hline 4. & Mode & 80,79 & 89,82 & 81,68 \\
\hline 5. & Standard Deviation & 14,49 & 16,56 & 16,28 \\
\hline 6. & Variance & 209,96 & 274,23 & 265,03 \\
\hline 7. & Range & 63 & 64 & 63 \\
\hline 8. & Maximun Score & 117 & 114 & 115 \\
\hline 9. & Minimum Score & 54 & 50 & 52 \\
\hline
\end{tabular}

\subsection{Hypothesis Testing}

After the path analysis was done, obtained the path coefficient that was used to test the research hypothesis. The criteria that was used in testing the hypothesis is if the path coefficient less than 0,05 then the path was meaningless.

Based on the description in the table 5, it was found that the value of $t_{\text {count }}$ of three path coefficients was greater than $t_{\text {table }}$ at $\alpha=0,05$. So, it can be concluded that the three path coefficients were significant.

Table 5. Description of Path Coefficient and Significance

\begin{tabular}{|c|c|c|c|}
\hline Path Coefficient & $\mathbf{t}_{\text {count }}$ & $\mathbf{t}_{\text {table }}$ & \multirow{2}{*}{ Description } \\
\cline { 3 - 3 } & & $\boldsymbol{\alpha}=\mathbf{0 , 0 5}$ & \\
\hline$\rho_{31}=0,296$ & 3,57 & 1,645 & Significant path \\
\hline$\rho_{41}=0,185$ & 2,06 & 1,645 & Significant path \\
\hline$\rho_{43}=0,297$ & 3,57 & 1,645 & Significant path \\
\hline
\end{tabular}

Based on the description above, it was concluded that the direct effect of Organizational Culture $\left(\mathrm{X}_{1}\right)$ on Work Motivation $\left(\mathrm{X}_{2}\right)$ with 0,296 , Organizational Culture $\left(\mathrm{X}_{1}\right)$ had a direct effect on Teachers Performance $\left(X_{3}\right)$ with 0,185 , and the direct effect of Work Motivation $\left(\mathrm{X}_{2}\right)$ on Teachers Performance $\left(\mathrm{X}_{3}\right)$ with 0,297 .

\subsection{Discussion}

\subsubsection{The Effect of Organizational Culture on Work Motivation}

The research findings showed that the organizational culture had a direct effect on work motivation with a path cofficient of 0,296 or $29 \%$. It means that there was a significant effect of organizational culture on work motivation. This finding supports the opinion of Colquitt, et al. (2009:64).

\subsubsection{The Effect of Organizational Culture on Teachers Performance}

Based on the findings, it was revealed that there was a direct effect of organizational culture on teachers performance with a path cofficient of 0,185 or $18 \%$. This means that there was a significant effect of organizational culture on teachers performance. This is in line with the view of Robbins and Judge (2009:608).

\subsubsection{The Effect of Work Motivation on Teachers Performance}

The research findings showed that the work motivation had a direct effect on teachers performance with a path cofficient of 0,297 or $29 \%$. It means that there was a significant effect of work motivation on teachers performance. This is in accordance with the opinion of Uno (2011:71), Colquitt, et al. (as cited in: Ambarita, et al., 2014:180) and Robbins and Judge (as cited in: Hasibuan, 2014:60).

\section{CONCLUSIONS AND RECOMMENDATIONS}

\subsection{Conclusions}

Based on the previous descriptions, so it can be concluded that:

1. The organizational culture had a positive direct effect on the work motivation. The value of the direct contribution of the organizational culture on the work motivation is 0,296 or $29 \%$.

2. The organizational culture had a positive direct effect on the teachers performance. The value of the direct contribution of the 
organizational culture on the teachers performance is 0,185 or $18 \%$.

3. The work motivation had a positive direct effect on the teachers performance. The value of the direct contribution of the work motivation on the teachers performance is 0,297 or $29 \%$.

\subsection{Recommendations}

Based on the conclusions, several suggestions are proposed as follows:

1. To improve work motivation, a good organizational culture is needed in schools, where teachers build positive values and norms jointly and sincerely that imitated by the entire of school community. With the realization of these values and norms in schools, teachers will be motivated to work.

2. In improving the performance of teachers, it is necessary to improve the organizational culture through the attitude and behavior of good teachers in building values and norms in schools. With good values and norms are implemented together, the teachers will show good performance in achieving the goals set.

3. The efforts to increase teachers work motivation is needed to improve teachers performance, through the fulfillment of social, reward and self-actualization needs. Teacher who has fulfilled his/her needs, $\mathrm{s} /$ he will work well. 


\section{REFERENCES}

[1] Ambarita, Biner, dkk. 2014. Perilaku Organisasi. Bandung: Alfabeta.

[2] Arikunto, Suharsimi. 2008. Prosedur Penelitian Suatu Pendekatan Praktek. Jakarta: PT. Rineka Cipta.

[3] Colquitt, Jason A., Jeffry A. LePine, Michael J. Wesson. 2009. Organizational Behavior: Improving Performance and Commitment in The Workplace. New York: McGraw-Hill Companies.

[4] Darmaningtyas. 2005. Pendidikan RusakRusakan. Yogyakarta: Lkis Yogyakarta.

[5] Depdikbud. 1990. Kamus Besar Bahasa Indonesia. Jakarta: Balai Pustaka.

[6] Departemen Pendidikan Nasional. 2007. Undang-Undang RI No. 20 Tahun 2003 tentang Sistem Pendidikan Nasional. Cetakan Kedua. Jakarta: Visimedia.

[7] Gibson. 2011. Organisasi, Perilaku, Struktur, dan Proses. Jakarta: Erlangga.

[8] Hasibuan, Novita Indah. 2014. Pengaruh Kepemimpinan Transformasional, Budaya Organisasi Dan Motivasi Kerja Terhadap Kepuasan kerja Dosen Di Fakultas Ekonomi Universitas Negeri Medan. Tesis. (Medan: PPs. Universitas Negeri Medan).

[9] Mangkunegara, Anwar Prabu. 2008. Perilaku dan Budaya Organisasi. Bandung: Refika Aditama.

[10] . 2013. Manajemen Sumber Daya Manusia Perusahaan. Bandung: PT. Remaja Rosdakarya.

[11] McShane, Steven and Mary Ann Von Glinow. 2008. Organizational Behavior. New York: McGraw-Hill Companies, Inc.

[12] Robbins, Stephen P. and Timothy A. Judge. 2009. Organizational Behavior. New Jersey: Pearson Education, Inc.

[13] 2011. Organizational Behavior. New Jersey: Pearson Education, Inc.

[14] Sihombing, Mayor. 2010. Hubungan Motivasi Kerja Guru dan Efektivitas Kepemimpinanan Kepala Sekolah dengan Kinerja Guru SMP Negeri Se-Kecamatan Percut Sei Tuan. Tesis. (Medan: PPs. Universitas Negeri Medan).

[15] Sugiyono. 2012. Statistika untuk Penelitian. Bandung: Alfabeta.

[16] Sutrisno, Aliet Noorhayati. 2014. Filsafat Pendidikan. Yogyakarta: DEEPUBLISH.

[17] Sutrisno, Edi. 2010. Budaya Organisasi. Jakarta: Kencana.
[18] Tim Pengembang Ilmu Pendidikan FIP - UPI. 2007. Ilmu dan Aplikasi Pendidikan. Bandung: PT. IMTIMA.

[19] Tim Pusat Studi Pancasila UGM. 2015. Membangun Kedaulatan Bangsa Berdasarkan Nilai-Nilai Pancasila:Pemberdayaan Masyarakat Dalam Kawasan Terluar, Terdepan, dan Tertinggal (3T). Yogyakarta: Pusat Studi Pancasila Universitas Gadjah Mada.

[20] Uno, Hamzah B. 2011. Teori Motivasi dan Pengukurannya; Analisis di Bidang Pendidikan. Jakarta: Bumi Aksara.

[21] Winardi. 2002. Motivasi dan Pemotivasian dalam Manajemen. Jakarta: PT. Raja Grafindo Persada.

[22] Wurinanda, Iradhatie. 2016. Kompetensi Kepala Sekolah Pengaruh Kinerja Guru. Jakarta: Okezone Kampus. (1 November 2016). 